similar issues with its own 'economic refugees' from certain neighbouring countries - should be able to understand well and appreciate Sarrazin's views on a somewhat more selective immigration regime which would favour those who integrate well and actually contribute to their new host country. There is thus no need to apply double-standards, i.e. demanding 'openness' from Western nations while at the same time practising restrictive and selective immigration policies of their own. In particular Muslim readers would be well-advised to take more seriously the concerns of Western host-societies rather than to brush them away by the already worn-out term 'islamophobia' - the long-term wellbeing of Muslim minorities in the West depends on it.

\title{
Notes
}

1. "Immigration Provocateur in Germany Crosses the Line", Der Spiegel, 30 August 2010, available online at http:/www.spiegel.de/international/germany/0,1518,714567,00.html (accessed on 24 November 2010).

2. See Christoph Marcinkowski, "Germany and the Muslim World", Islam and Civilisational Renewal 1, no. 3 (April 2010), 519-22.

3. See on this issue Christoph Marcinkowski, Islam in Europe: Reflections on Present Trends and Future Challenges, IAIS Monograph Series 5 (Kuala Lumpur: IAIS Malaysia, 2011).

4. "18 Prozent der Deutschen würden Sarrazin wählen”, Berliner Morgenpost, 6 September 2010, available online at http://www.morgenpost.de/printarchiv/titelseite/article1390251/18-Prozent-derDeutschen-wuerden-Sarrazin-waehlen.html (accessed on 24 November 2010).

5. As a matter of fact, Sarrazin was born in the Central German town of Gera to a doctor and the daughter of a West Prussian landowner. His paternal family - French Huguenots (Protestants) - originates from Burgundy, while his grandmother was English-Italian. Ironically, he has explained that his name means 'Saracen' (i.e. 'Muslim') and is common in Southern France, being derived from the Arab pirates which were called 'Saracens' in the Middle Ages.

6. See "Migration in Deutschland: Mehr Auswanderer als Einwanderer", Frankfurter Rundschau, 26 May 2010, available online at http://www.fr-online.de/politik/mehr-auswanderer-alseinwanderer/-/1472596/4464748/-/index.html (accessed on 21 January 2011). This reviewer, for instance, left Germany in 1995.

\section{Barry Wain, Malaysian Maverick: Mahathir Mohamad in Turbulent Times}

(New York: Palgrave, Macmillan, 2009), 363 pp. ISBN: 978-0230238732.

US\$ 81.00

\section{Osman Bakar International Institute of Advanced Islamic Studies (IAIS) Malaysia}

The content of this book under review seems to justify its title. Those who know Mahathir Mohamad - the former Malaysian Prime Minister - quite well both as a person and as a political leader would have no hesitation in agreeing with the book's author to call him the Malaysian maverick. Barry Wain has the qualification to write about Mahathir's political career and his successes and failures as a political 
leader. An Australian journalist with much experience in the profession, Wain has lived in Asia for nearly 40 years, including covering Malaysia from 1984 to 1992 for the Asian Wall Street Journal. He is now writer-in-residence at the Institute of Southeast Asian Studies in Singapore. The book provides a good descriptive and interpretive account of Mahathir's political life and thought. Wain tries to strengthen his interpretive account with the help of interviews and the numerous writings on Mahathir available to him. There are more than enough events and episodes in Mahathir's life narrated by Wain to support the author's - and many Malaysians'characterisation of Malaysia's longest serving and most controversial Prime Minister as a maverick. Wain's readable account would be particularly helpful to first-time readers of Mahathir.

The book consists of 13 chapters which are divided into three parts. The titles of the three parts have been chosen so as to conform to a chronological requirement. The first part - "The Making of a Malay Champion" - corresponds to the first phase of Mahathir's political life and thought that spans decades, starting from his first entry into politics in the pre-Second World War period until the eve of his assumption of office as Prime Minister in 1981. This was the period that first saw Mahathir making a name for himself as an exponent of Malay nationalism to the point of being labelled by some as a 'Malay ultra', expelled from UMNO (Malaysia's largest political party) in July 1969 for his stinging attacks on Tunku Abdul Rahman, and rehabilitated by Tun Abdul Razak in 1972 only to rise steadily within the Party's ranks to the post of Deputy President which traditionally carries with it the coveted office of the Deputy Prime Minister.

The book's second part - "Prime Minister for Life, Almost" - corresponds to the second phase of Mahathir's political life and thought which spans the 22 years of his Premiership. Mahathir succeeded Hussein Onn as Prime Minister in 1981 and stepped down in October 2003 in favour of Abdullah Ahmad Badawi as his successor. What Wain wants to tell readers through the title of this part of the book is that this second phase could also have been the last one if only Mahathir had not felt the pressure to step down. That is to say, he would still be Prime Minister today and would remain so until his death! Wain tells us that in itself, the second part, which he describes as "the body of the book," does not have its nine chapters arranged in a chronological way. This is because this part is "a thematic treatment of Dr Mahathir's leadership of Malaysia" (p. vii). If by "thematic treatment" is meant a discussion of the major and significant issues that the Mahathir leadership had to face, be these out of Mahathir's own making or otherwise, then there are dozens of them. Wain's selection of the nine 'themes' to guide him in his assessment of the quality of Mahathir's leadership merits some praise. This is because these themes point to the major landmarks of the Mahathir leadership which exhibited both its successes and its failures. 
Moreover, the issues that failed him, as enumerated by Wain, did not disappear with his resignation from office largely by virtue of their highly controversial nature and massive impacts on the Malaysian public. They were a legacy to Abdullah Ahmad Badawi and Najib Tun Abdul Razak, and their impact continues. This is true, for example, of the issues that are of central concern to Chapter 5 ("A Volatile Mix of Business and Politics"), Chapter 6 ("Scandal, What Scandal?"), Chapter 7 ("Big, Bigger, Bust"), and Chapter 11 ("The Destruction of a Designated Heir"). The issues of corruption arising mainly from the kind of mix of business and politics familiar to the Mahathir Administration (Chapter 5), the issues of "financial scandals that exploded with startling regularity, some of them truly spectacular", almost all of which were "involving the government directly", and of "massive wastage" (Chapter 6, p. 149), the issue of "mega projects" (Chapter 7), and the issue of Anwar Ibrahim's moral credibility to be a leader, are all still very much alive, particularly the last one. Anwar's sodomy trial, currently under way, is almost a repeat of his sodomy trial during Mahathir's rule. Wain attributes both Mahathir's major successes and major failures to what he calls the latter's "think big" philosophy "which prompted a public craze for setting all sorts of world records". But we could have also said that both facets of Mahathir's political life as Prime Minister were equally attributable to doing things and overcoming challenges 'My Way'. Anyway, for better or for worse, the portrait of "Mahathir, the Malaysian maverick" shines through all the chapters in Part II of the book.

The third and final part of the book - "Turmoil in Retirement" - corresponds to Mahathir's life in retirement. Both Chapter 12 ("A Bare-Knuckle Brawl Over One Man's Legacy") and Chapter 13 ("A Place in History") are more interesting to read than the earlier chapters because these bring into focus the issues of how Mahathir's successors - Abdullah Ahmad Badawi and Najib Tun Razak - try to deal with his legacy under his keen watch and in doing so find themselves in a tense and turbulent relationship with him and how Mahathir seeks to define his best legacy to the nation in the light of which his place in history would be evaluated. Abdullah reversed a good number of Mahathir's policies and the latter saw this as a threat to his legacy leading him to break his promise not to indulge in politics and "not to interfere in Malaysian government affairs" (Chapter 12, p. 307). Wain quoted these words of Mahathir: "No, I have already made it very clear that when I leave, I leave completely" (p. 307). But as events unfolded in Malaysian politics Mahathir's supposed life in retirement turns into a return to active politics. He played an instrumental role in shortening Abdullah's Premiership and putting Najib in the No.1 leadership spot.

Wain has managed in the last two chapters to bring into focus in the minds of readers the 'love-hate triangle' in the relationships involving Mahathir, Abdullah and Najib the implications of which for Malaysia are by no means yet certain. 
Mahathir's place in history is a contested issue and a difficult one to judge largely because he is still making history. Meanwhile, the long awaited book A Doctor in the House: the Memoirs of Tun Dr Mahathir Mohamad has just come out. Those interested in the issue of Mahathir's legacy and his place in history are well advised to read this memoir. Wain's book would be of great help to readers who seek a critical evaluation of the memoir.

\section{Seyyed Hossein Nasr (in conversation with Muzaffar Iqbal), Islam, Science, Muslims, and Technology}

(Kuala Lumpur: Islamic Book Trust, and Sherwood Park: Al-Qalam Publishing, 2010, repr.), xii+212 pp. ISBN: 978-0-9738744-2-6 (paperback). US\$19.85

Norhayati Mustapha International Institute of Advanced Islamic Studies (IAIS) Malaysia

At the outset Muzaffar Iqbal explains the context within which the book was conceived by relating his first encounter with Professor Seyyed Hossein Nasr in Islamabad, March 1995, where the latter was due to deliver a keynote address at an international conference organised by the OIC Standing Committee on Scientific and Technological Cooperation (COMSTECH) on "Science in Islamic Polity in the Twenty-First Century". Nasr follows with his essay on "The Cosmos as Subject of Scientific Study", after which four separate conversations occupy the second section while the third and last sections present the text of Nasr's keynote address at the said conference.

In the conversation on "Islam, Science and Muslims", Nasr emphasises the need to create an authentic Islamic philosophy and science of nature on the basis of both our own scientific tradition and discoveries of the Western world. He mentions Islamic institutions which offer modern sciences and other subjects taught in modern Western institutions but in the matrix of Islamic thought, one of which he set up himself, i.e. the former Imperial Iranian Academy of Philosophy. Throughout he laments the error of modern science in forgetting the spiritual dimension in nature, likening it to "cutting off the Hands of God from His creation", and puts forth the idea of creating islands within the Muslim world for the continuation and practice of alternative technologies from the Islamic viewpoint to include the fields of medicine, pharmacology and agriculture.

Conversing on "Islam, Muslims, and Modern Technology", Nasr defines the word 'technology' from its origins in Greek (téchnē, meaning 'an art'), Latin (ars, also meaning 'an art'), Persian (șan 'at which refers to both 'technology' and 'art') and Arabic (sina 'ah, with the same meaning), inferring that linguistically and 